\title{
IDŐJÁRÁS
}

Quarterly Journal of the Hungarian Meteorological Service

Vol. 123, No. 4, October-December, 2019, pp. 455-468

\section{Cyclical variability of seasonal precipitation in Poland}

\author{
Jadwiga Nidzgorska-Lencewicz and Małgorzata Czarnecka \\ Department of Environmental Management \\ West Pomeranian University of Technology in Szczecin \\ Papieża Pawta VI St 3A, 71-459 Szczecin, Poland \\ *Corresponding Author E-mail: jnidzgorska@zut.edu.pl
}

(Manuscript received in final form July 2, 2018)

\begin{abstract}
The aim of the present paper was an attempt to detect the recurring fluctuations in the course of seasonal sums of precipitation in Poland. The basic material consisted of monthly sums of atmospheric precipitation obtained from 37 IMGW-BIP weather stations from the period $1951-2016$, excluding the mountain areas. Spectral analysis was performed concerning precipitation sums in the four calendar seasons: spring (March-May), summer (June-August), autumn (September-November), winter (December - February). The results of the spectral analyses showed that the changes in seasonal precipitation sums recorded in the analyzed multiannual period occurred in numerous, statistically significant cycles, with a clear predominance of the cycles with the following length: 4.0, 4.6, 4.9, 5.3, 5.8, 6.4, and 7.1 years. It was found that the winter season is characterized by the most pronounced cyclicality (cycles of 6.4 years), whereas the spring season is marked by the highest variability in terms of periodicity.
\end{abstract}

Key-words: seasons, variability, spectral analysis, cycle

\section{Introduction}

Changes occurring in the global climate system encourage deeper analysis of variability of climatic conditions on regional or local scales (Marosz et al., 2011). The need for research on climate change is also indicated by the work of Kaszewski (2015), who developed a synthesis of studies conducted by Polish climatologists. The most commonly studied issues are the basic climatic 
elements - air temperature and atmospheric precipitation. The results of numerous studies unequivocally point to the stipulation that the ongoing climate warming is in fact empirically confirmed to take place in Poland. Atmospheric precipitation, however, is not subject to such obvious changes (Kirschenstein, and Baranowski, 2005; Kożuchowski, 1996, 2004; Boryczka and StopaBoryczka, 2000; Żmudzka, 2009). Depending on the analyzed period, the annual precipitation sums show a statistically insignificant upward or downward trend (Żmudzka, 2002; Mager et al., 2009; Marosz et al., 2011; Czarnecka and Nidzgorska-Lencewicz, 2012; Skowera et al., 2014). A similar situation is observed concerning the extreme precipitation. The study by Marosz (2011) showed that totals and the number of days with extreme precipitation are insignificant and spatially incoherent. Eupikasza (2010) presented the dominance of long-term (1951-2006) decreasing tendencies of various indices of extreme precipitation in Poland. Additionally, the changes in the values of seasonal atmospheric precipitation do not show a statistically significant linear trend (Czarnecka and Nidzgorska-Lencewicz, 2012). In spite of the abovementioned facts, the pluvial regime in Poland has changed over the last few decades. In the south part of Poland, the number of days with very light $(0.1-1.0$ $\mathrm{mm})$ and light precipitation $(1.1-5.0 \mathrm{~mm})$ showed a clear increase, and the number of days with $20.1-30.0 \mathrm{~mm}$ of precipitation was found to decrease (Skowera et al., 2016). An upward trend of an increase in precipitation during the spring and autumn season, and the decreasing share of summer precipitation in the annual totals is the common phenomena manifested over the area of Poland (Czarnecka and Nidzgorska-Lencewicz, 2012; Szwed, 2018). According to Degirmendžić et al. (2004), this is the fundamental reason behind weakening of the continental nature of the climate. The forecasts by Szwed (2018) indicate that the annual totals of precipitation in Poland will increase, precipitation recorded in the warm season will continue to decrease, and precipitation in the cold season is expected to increase. Indeed, this is an extremely disadvantageous trend as there are currently many regions in Poland affected with water shortages during the growing season, and the situation is likely to aggravate. It is a recognized fact that water shortages are responsible for numerous adverse natural and economic phenomena, as well as deteriorating functioning of society (Kędziora et al., 2014). Droughts result in calculable economic loss and contribute to a significant reduction in yield of cultivated plants (Żarski et al., 2014, 2017). Recently, drought is recorded increasingly more often in Poland, particularly since 1992 (Doroszewski et al., 2014).

The changes in the basic features assessed with the use of linear trend are not statistically significant due to the fact that the changes of the most labile element of the climate (assuredly, the precipitation) can be expressed as irregular fluctuations. However, studies on identifying the natural periodicity in the course of meteorological elements are not frequently conducted in Poland. Admittedly, the identified cyclicality in the course of precipitation is based on 
long-term, at least century-long, measuring series, yet the results are limited to one or only few stations in Poland (Boryczka and Stopa-Boryczka, 2004; Degirmendžić et al., 2004; Miętus, 1996; Miler and Miler, 2005; Miler and Okoński, 2011; Twardosz and Cebulska 2005; Czarnecka and NidzgorskaLencewicz, 2016). So far, the literature on the subject with reference to Poland is lacking in studies concerned with identifying the natural fluctuations in sums of precipitation in the whole area of Poland. The present study is an attempt to provide the missing information.

\section{Materials and methods}

The study is based on the monthly sums of atmospheric precipitation from the period 1951-2016 obtained from 37 meteorological stations of the Institute of Meteorology and Water Management - National Research Institute (IMGWPIB), location of which is presented in Fig. 1. The analysis does not include the mountainos areas. More than half of the stations is located at an altitude below $150 \mathrm{~m}$ a.s.1., and only 6 stations are located at an altitude of over $200 \mathrm{~m}$ a.s.1. including the two stations (Jelenia Góra and Kłodzko), which are located at an altitude of over $300 \mathrm{~m}$ a.s.l. The analysis considers the totals of the calendar seasons, i.e., spring (March-May), summer (June-August), autumn (September - November), and winter (December - February).

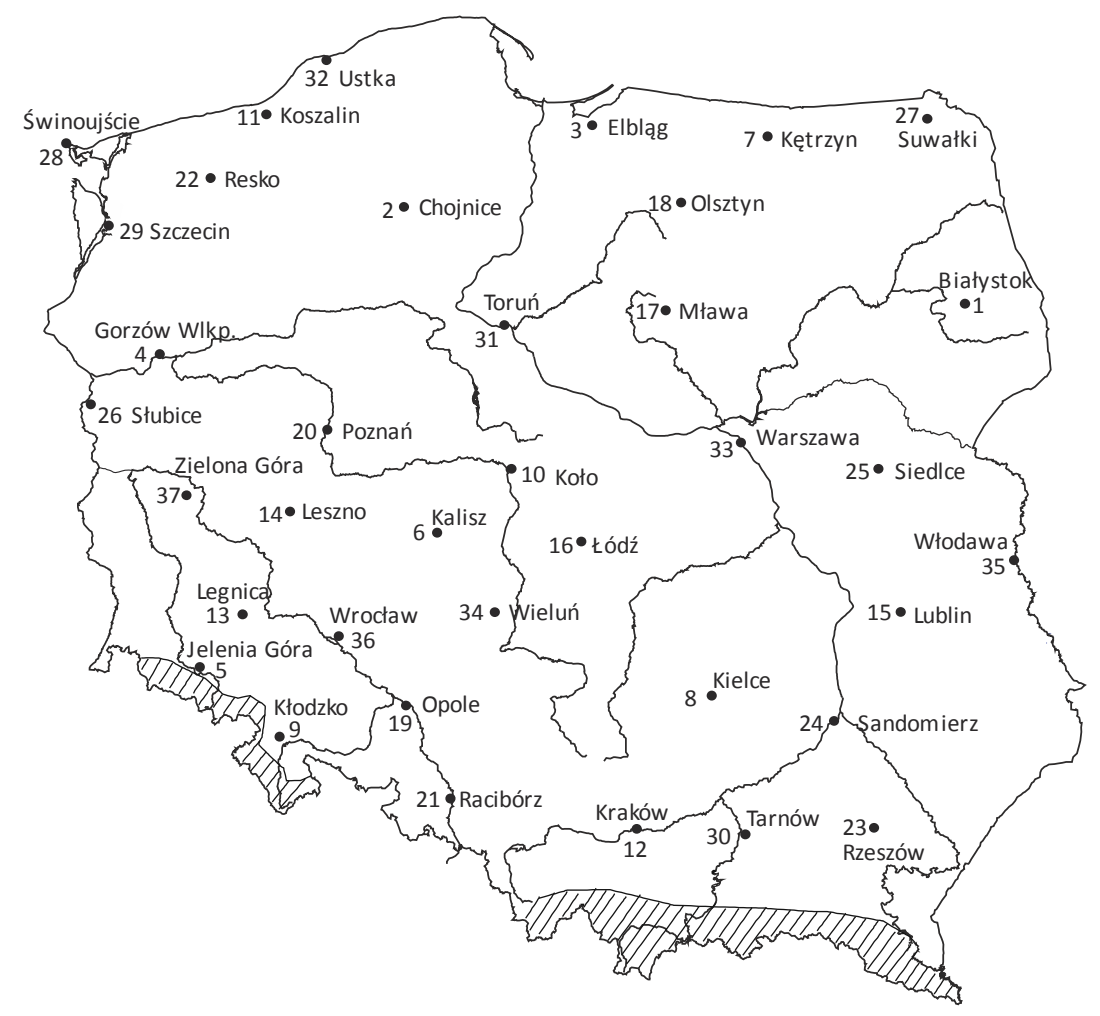

Fig. 1. Location of meteorological stations of IMGW-PIB considered in the study (mountain areas are not considered in this study). 
For the purpose of identifying periodic phenomena, harmonic analysis also known as Fourier spectral analysis, is used (Fortuniak, 2004; Miler and Okoński, 2011). By means of decomposition of time series, this analysis enables determination of periodicity often distorted by a random component. The condition for the application of spectral analysis is the stationarity of the analyzed series. The analyzed stochastic process was brought down to the stationary series by calculating the first increments. Then, the series was smoothed by Hamming spectral window 5, which resulted in reduction of random noise and facilitated identification of frequency range which contributes the most to the general harmonic structure of the analyzed series of atmospheric precipitation. The significance of periodicity was tested with Bartlett's Kolmogorov-Smirnov test and Fisher's Kappa. The calculations were made with the use of Statistica 10 software.

\section{Results}

The mean annual sum of precipitation calculated on the basis of the results obtained from 37 stations from the period 1951-2016, excluding the mountainous area, amounted to $596 \mathrm{~mm}$ and was almost the same as that recorded for the 60-year-long period 1951-2010 (Czarnecka and NidzgorskaLencewicz, 2012), and the average from 53 stations in the standard 30-year-long period 1971-2000 (Ziernicka-Wojtaszek, 2006). On average, the smallest total precipitation i.e., approximately $410 \mathrm{~mm}$, was identified in 1982, whereas twice the amount was recorded in 2010 (Fig. 2). Annual precipitation, of a sum of more than $700 \mathrm{~mm}$, was recorded more frequently in the first half of the analyzed multiannual period, and a longer series of precipitation of lower or comparable values to the average amount was recorded in the period 19821997. Mean precipitation totals from 37 stations in spring, summer, autumn, and spring were: 130, 223, 138, and 103, respectively. The maximum and minimum seasonal sums of precipitation occurred in different years, yet all of them were recorded in the 20th century. Pluvial continentalism in Poland is manifested by more than double predominance of summer precipitation over precipitation recorded in winter. Sums of precipitation in the three summer months constitute approximately $38 \%$ of the annual total, while winter precipitation - merely approximately $17 \%$ (Fig. 3). Nevertheless, percentage share of seasonal precipitation in the annual sum shows very high inter-annual variability - the highest in summer and the smallest in winter. For example, in the summer of 1994, precipitation amounted to only $22 \%$ of the annual total, whereas in $2011-$ to as much as $51 \%$. Although mean precipitation values in the transitional seasons are comparable, a clear dominance of autumn precipitation is evident and distinguished by not only the highest values of the coefficient of variation in the sums (Vs=27\% - Fig. 2), but also by greater fluctuations (as compared to spring) of the percentage share in the annual total (Fig. 3). 

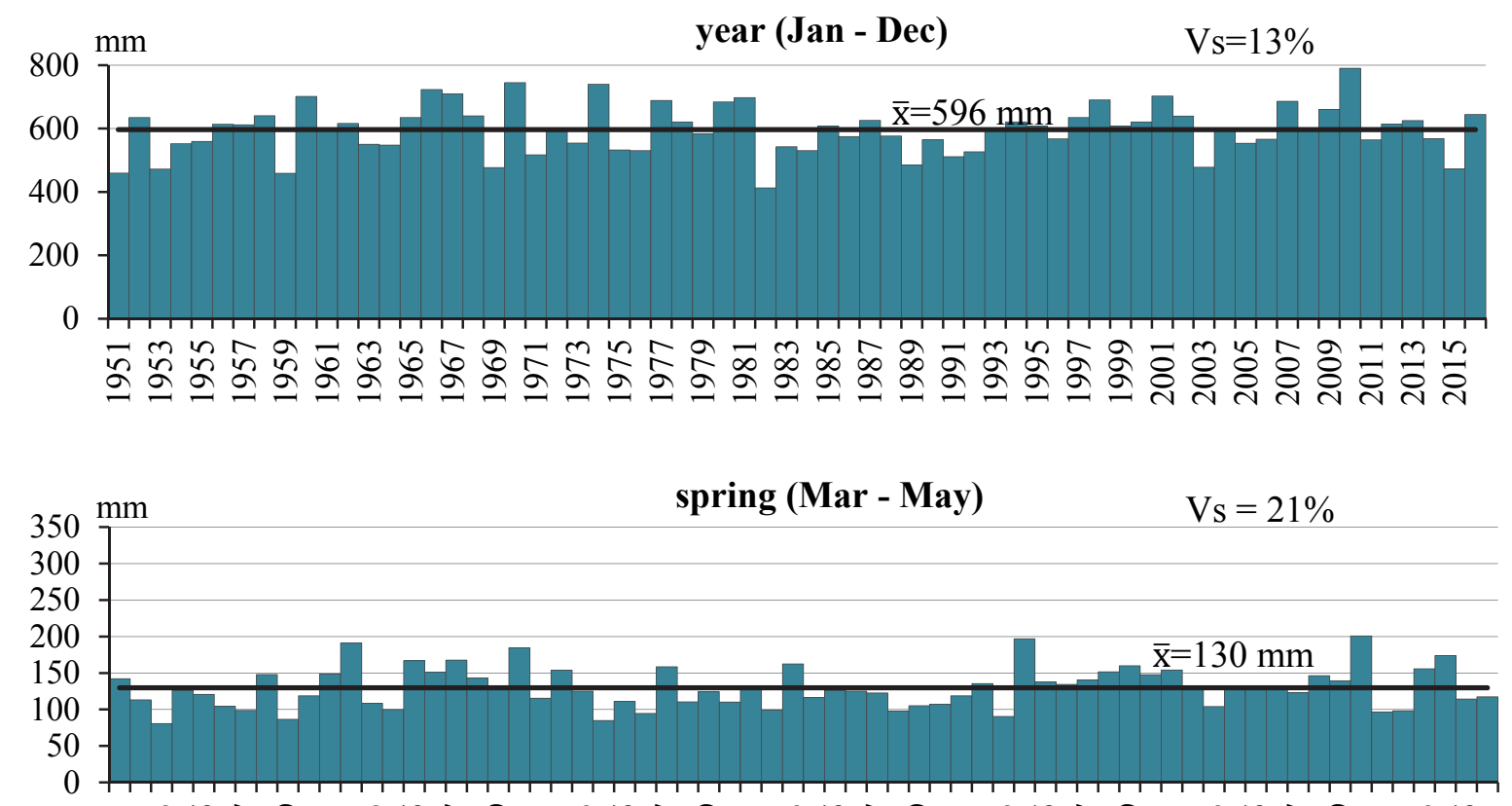

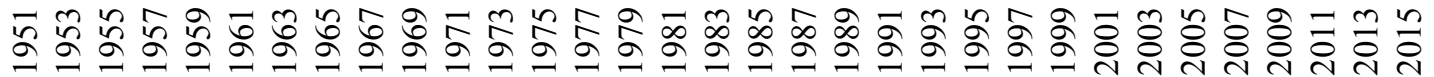
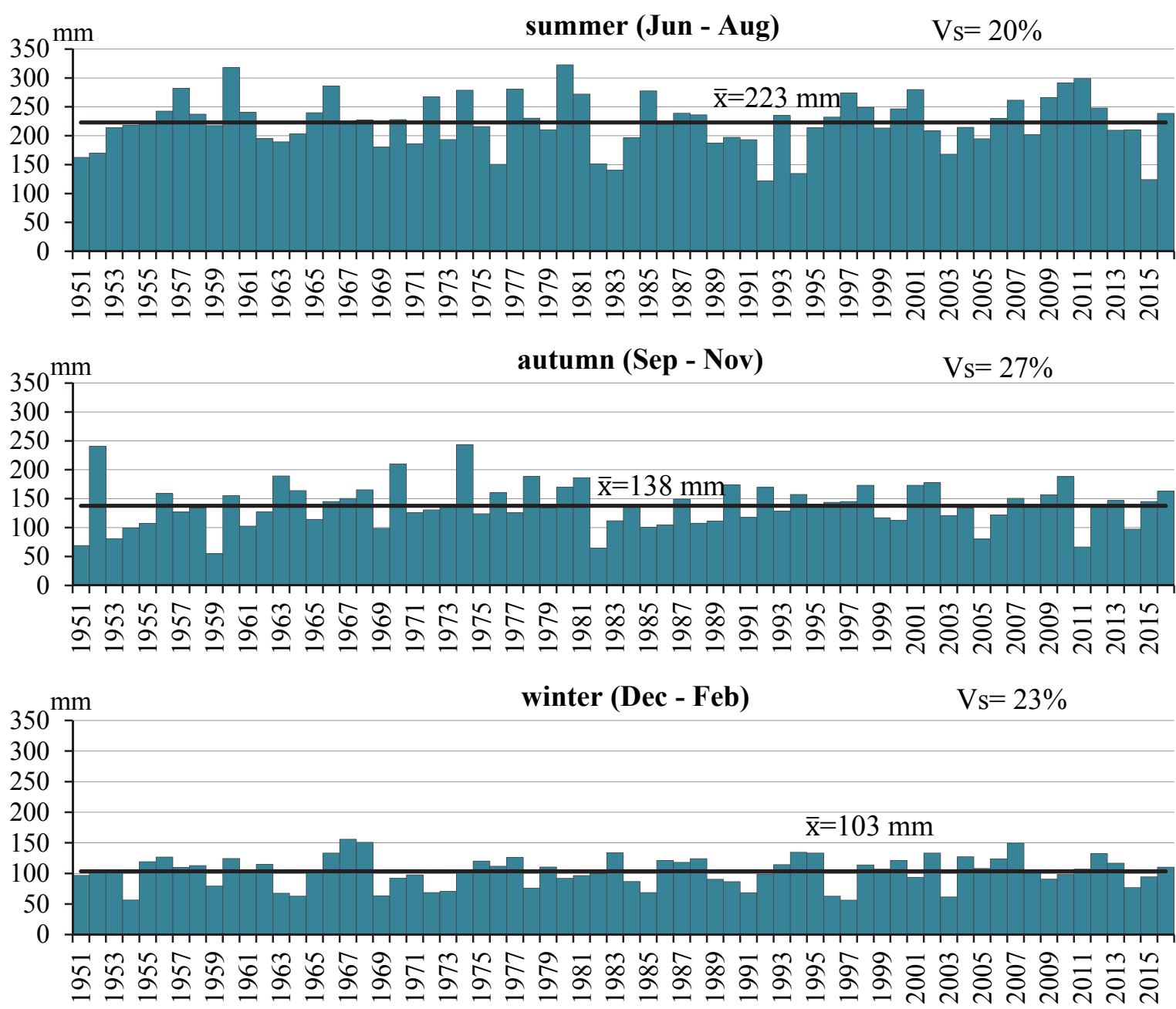

Fig. 2. Variability in the annual and seasonal precipitation sums $(\mathrm{mm})$ in Poland (mean of 37 stations) in the period 1951-2016. 


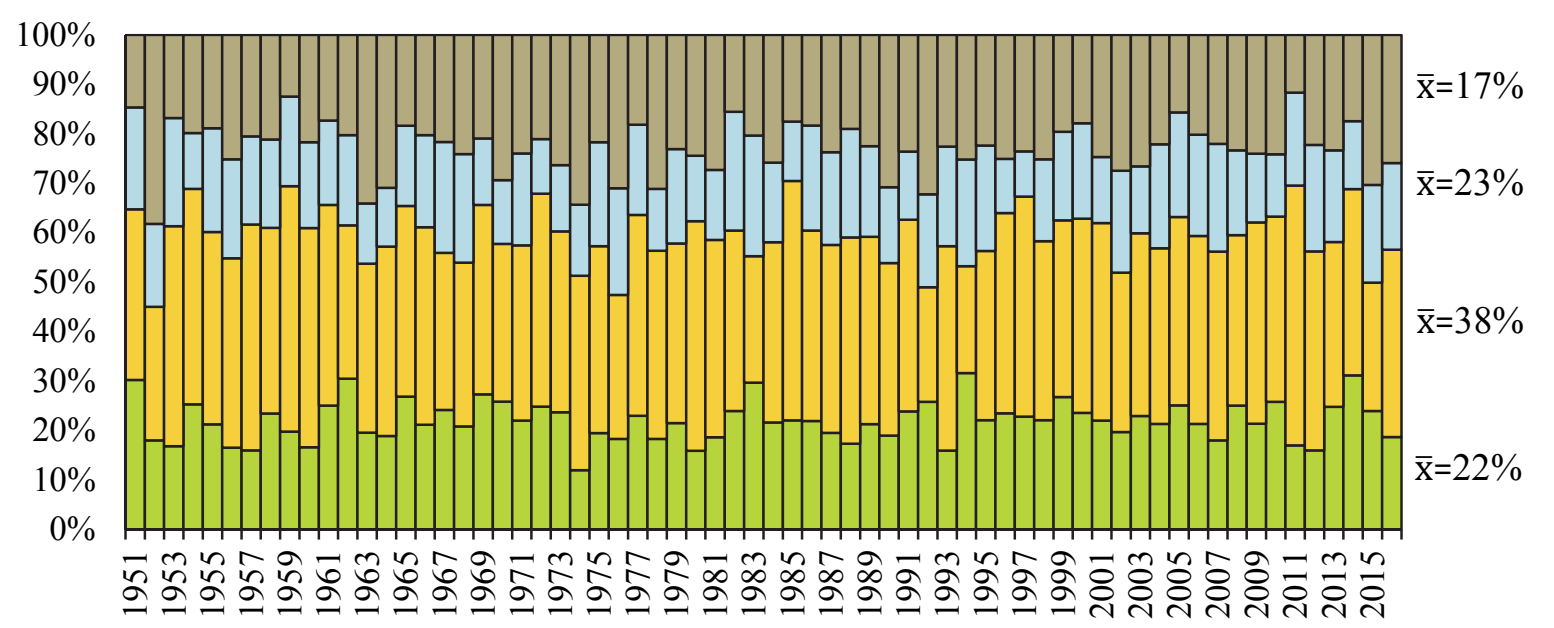

$\square$ spring $\square$ summer $\square$ winter $\square$ autumn

Fig. 3. Variability of percentage share of seasonal precipitation in the annual sums in Poland (mean of 37 stations) in the period 1951-2016.

The basic features of atmospheric precipitation in the 66-year-long period (1951-2016) as per individual stations are presented in Table 1. The values of annual and seasonal precipitation - both as regards the means and the extremes, do not differ from those determined for the 60-year-long period of 1951-2010 (Czarnecka and Nidzgorska-Lencewicz, 2012). In most of the stations, the recorded mean annual sums range from 500 to $600 \mathrm{~mm}$, and the higher values were recorded in Koszalin and Tarnów. Among the 36 analyzed stations, the minimum annual sum of precipitation was recorded in Kalisz. In the analyzed multiannual period, at eight stations, the maximum annual sum of precipitation was determined in 2010, and the highest values $(1200 \mathrm{~mm})$ were recorded in Tarnów. At many stations, the smallest sums of precipitation occurred in 1982. The series of 1982-1984 is termed by Doroszewski et al. (2014) as a period of severe drought in Poland. 
Table 1. Mean (a), maximum (b), and minimum (c) sum in $\mathrm{mm}$ and coefficient of variation (d) in \% of precipitation in selected stations in Poland, in the period 1951-2016

\begin{tabular}{|c|c|c|c|c|c|c|c|c|}
\hline $\begin{array}{c}\text { Station } \\
\text { number } \\
\text { in Fig.1 } \\
\end{array}$ & $\begin{array}{l}\text { Height } \\
\text { in } \mathrm{m} \\
\text { n.p.m. } \\
\end{array}$ & Station & & $\begin{array}{c}\text { Spring } \\
\text { Mar-May }\end{array}$ & $\begin{array}{l}\text { Summer } \\
\text { Jun-Aug }\end{array}$ & $\begin{array}{l}\text { Autumn } \\
\text { Sep-Nov }\end{array}$ & $\begin{array}{c}\text { Winter } \\
\text { Dec-Feb }\end{array}$ & $\begin{array}{c}\text { Year } \\
\text { Jan-Dec }\end{array}$ \\
\hline \multirow{4}{*}{1} & \multirow{4}{*}{139} & \multirow{4}{*}{ Białystok } & $\mathrm{a}$ & 128 & 218 & 140 & 103 & 590 \\
\hline & & & $\mathrm{b}$ & 245 & 414 & 336 & 185 & 858 \\
\hline & & & $\mathrm{c}$ & 46 & 94 & 30 & 46 & 336 \\
\hline & & & $\mathrm{d}$ & 30 & 31 & 39 & 29 & 17 \\
\hline \multirow{4}{*}{2} & \multirow{4}{*}{172} & \multirow{4}{*}{ Chojnice } & $\mathrm{a}$ & 119 & 216 & 138 & 103 & 577 \\
\hline & & & $\mathrm{b}$ & 247 & 489 & 286 & 211 & 835 \\
\hline & & & $\mathrm{c}$ & 46 & 75 & 26 & 38 & 311 \\
\hline & & & d & 33 & 34 & 37 & 37 & 19 \\
\hline \multirow{4}{*}{3} & \multirow{4}{*}{38} & \multirow{4}{*}{ Elbląg } & $\mathrm{a}$ & 122 & 238 & 186 & 121 & 668 \\
\hline & & & $\mathrm{b}$ & 217 & 512 & 343 & 215 & 938 \\
\hline & & & $\mathrm{c}$ & 52 & 81 & 63 & 30 & 354 \\
\hline & & & d & 28 & 35 & 32 & 30 & 19 \\
\hline \multirow{4}{*}{4} & \multirow{4}{*}{65} & \multirow{4}{*}{$\begin{array}{c}\text { Gorzów } \\
\text { Wielkopolski }\end{array}$} & $\mathrm{a}$ & 121 & 191 & 123 & 112 & 547 \\
\hline & & & b & 198 & 326 & 271 & 200 & 752 \\
\hline & & & $\mathrm{c}$ & 46 & 80 & 47 & 49 & 337 \\
\hline & & & d & 31 & 27 & 37 & 32 & 17 \\
\hline \multirow{4}{*}{5} & \multirow{4}{*}{342} & \multirow{4}{*}{ Jelenia Góra } & $\mathrm{a}$ & 165 & 283 & 144 & 105 & 697 \\
\hline & & & $\mathrm{b}$ & 279 & 559 & 297 & 177 & 1007 \\
\hline & & & $\mathrm{c}$ & 91 & 132 & 24 & 50 & 450 \\
\hline & & & d & 26 & 30 & 33 & 30 & 18 \\
\hline \multirow{4}{*}{8} & \multirow{4}{*}{268} & \multirow{4}{*}{ Kielce } & $\mathrm{a}$ & 140 & 237 & 135 & 117 & 630 \\
\hline & & & b & 296 & 446 & 324 & 233 & 1000 \\
\hline & & & $\mathrm{c}$ & 65 & 122 & 29 & 48 & 438 \\
\hline & & & $\mathrm{d}$ & 33 & 32 & 36 & 31 & 18 \\
\hline \multirow{4}{*}{9} & \multirow{4}{*}{316} & \multirow{4}{*}{ Kłodzko } & $\mathrm{a}$ & 141 & 258 & 124 & 75 & 598 \\
\hline & & & $\mathrm{b}$ & 281 & 454 & 225 & 119 & 854 \\
\hline & & & $\mathrm{c}$ & 59 & 95 & 38 & 27 & 339 \\
\hline & & & d & 30 & 30 & 35 & 28 & 17 \\
\hline \multirow{4}{*}{12} & & & $\mathrm{a}$ & 161 & 267 & 145 & 107 & 681 \\
\hline & 206 & Kroków & $\mathrm{b}$ & 369 & 518 & 319 & 187 & 1021 \\
\hline & 200 & мrakow & c & 74 & 101 & 44 & 56 & 470 \\
\hline & & & d & 31 & 28 & 38 & 27 & 17 \\
\hline & & & $\mathrm{a}$ & 139 & 217 & 134 & 101 & 590 \\
\hline & & & $\mathrm{b}$ & 337 & 376 & 299 & 176 & 821 \\
\hline 15 & $1 / 1$ & Lublin & $\mathrm{c}$ & 64 & 68 & 33 & 38 & 349 \\
\hline & & & d & 34 & 26 & 42 & 29 & 18 \\
\hline & & & $\mathrm{a}$ & 126 & 215 & 127 & 102 & 569 \\
\hline & & & $\mathrm{b}$ & 256 & 382 & 230 & 161 & 780 \\
\hline 16 & 181 & Łodz & $\mathrm{c}$ & 56 & 83 & 22 & 37 & 338 \\
\hline & & & d & 30 & 30 & 34 & 31 & 17 \\
\hline & & & $\mathrm{a}$ & 125 & 229 & 159 & 114 & 627 \\
\hline & & & $\mathrm{b}$ & 241 & 374 & 295 & 196 & 920 \\
\hline 18 & 133 & Olsztyn & $\mathrm{c}$ & 42 & 81 & 57 & 34 & 342 \\
\hline & & & $\mathrm{d}$ & 34 & 31 & 31 & 30 & 19 \\
\hline
\end{tabular}


Table 1. Continued

\begin{tabular}{|c|c|c|c|c|c|c|c|c|}
\hline $\begin{array}{l}\text { Station } \\
\text { number } \\
\text { in Fig.1 }\end{array}$ & $\begin{array}{l}\text { Height } \\
\text { in } \mathrm{m} \\
\text { n.p.m. }\end{array}$ & Station & & $\begin{array}{c}\text { Spring } \\
\text { Mar-May }\end{array}$ & $\begin{array}{l}\text { Summer } \\
\text { Jun-Aug }\end{array}$ & $\begin{array}{l}\text { Autumn } \\
\text { Sep-Nov }\end{array}$ & $\begin{array}{c}\text { Winter } \\
\text { Dec-Feb }\end{array}$ & $\begin{array}{c}\text { Year } \\
\text { Jan-Dec }\end{array}$ \\
\hline \multirow{4}{*}{20} & \multirow{4}{*}{86} & \multirow{4}{*}{ Poznań } & $\mathrm{a}$ & 117 & 193 & 114 & 98 & 582 \\
\hline & & & $\mathrm{b}$ & 234 & 306 & 211 & 177 & 886 \\
\hline & & & $\mathrm{c}$ & 38 & 60 & 30 & 37 & 317 \\
\hline & & & $\mathrm{d}$ & 34 & 32 & 38 & 31 & 20 \\
\hline \multirow{4}{*}{21} & \multirow{4}{*}{189} & \multirow{4}{*}{ Racibórz } & $\mathrm{a}$ & 154 & 254 & 137 & 92 & 637 \\
\hline & & & $\mathrm{b}$ & 305 & 473 & 281 & 209 & 1006 \\
\hline & & & $\mathrm{c}$ & 54 & 73 & 46 & 23 & 254 \\
\hline & & & d & 31 & 33 & 36 & 33 & 20 \\
\hline \multirow{4}{*}{23} & \multirow{4}{*}{200} & \multirow{4}{*}{ Rzeszów } & $\mathrm{a}$ & 153 & 243 & 139 & 98 & 632 \\
\hline & & & $\mathrm{b}$ & 307 & 460 & 320 & 167 & 1008 \\
\hline & & & $\mathrm{c}$ & 60 & 92 & 39 & 49 & 340 \\
\hline & & & $\mathrm{d}$ & 30 & 32 & 41 & 30 & 21 \\
\hline \multirow{4}{*}{24} & \multirow{4}{*}{202} & \multirow{4}{*}{ Sandomierz } & $\mathrm{a}$ & 133 & 227 & 123 & 83 & 566 \\
\hline & & & $\mathrm{b}$ & 224 & 456 & 293 & 181 & 865 \\
\hline & & & $\mathrm{c}$ & 75 & 116 & 30 & 32 & 376 \\
\hline & & & d & 30 & 32 & 41 & 40 & 19 \\
\hline \multirow{4}{*}{27} & \multirow{4}{*}{165} & \multirow{4}{*}{ Suwałki } & $\mathrm{a}$ & 121 & 221 & 151 & 103 & 597 \\
\hline & & & $\mathrm{b}$ & 224 & 463 & 299 & 188 & 829 \\
\hline & & & $\mathrm{c}$ & 53 & 89 & 59 & 28 & 323 \\
\hline & & & d & 30 & 32 & 35 & 31 & 17 \\
\hline \multirow{4}{*}{28} & \multirow{4}{*}{5} & \multirow{4}{*}{ Świnoujście } & $\mathrm{a}$ & 119 & 180 & 146 & 118 & 564 \\
\hline & & & b & 249 & 409 & 313 & 182 & 761 \\
\hline & & & $\mathrm{c}$ & 50 & 53 & 60 & 45 & 377 \\
\hline & & & $\mathrm{d}$ & 31 & 33 & 33 & 30 & 17 \\
\hline \multirow{4}{*}{29} & \multirow{4}{*}{1} & \multirow{4}{*}{ Szczecin } & $\mathrm{a}$ & 120 & 188 & 127 & 109 & 543 \\
\hline & & & $\mathrm{b}$ & 234 & 364 & 244 & 179 & 795 \\
\hline & & & $\mathrm{c}$ & 57 & 70 & 64 & 43 & 390 \\
\hline & & & $\mathrm{d}$ & 31 & 29 & 31 & 31 & 16 \\
\hline \multirow{4}{*}{31} & & & $\mathrm{a}$ & 108 & 211 & 118 & 90 & 528 \\
\hline & 69 & Tornú & b & 273 & 557 & 214 & 152 & 846 \\
\hline & 69 & Iorun & $\mathrm{c}$ & 44 & 86 & 28 & 31 & 312 \\
\hline & & & $\mathrm{d}$ & 38 & 35 & 37 & 33 & 21 \\
\hline & & & $\mathrm{a}$ & 116 & 216 & 219 & 142 & 693 \\
\hline & & & $\mathrm{b}$ & 296 & 361 & 413 & 250 & 1019 \\
\hline 32 & 6 & Ustka & $\mathrm{c}$ & 44 & 85 & 86 & 64 & 424 \\
\hline & & & $\mathrm{d}$ & 36 & 34 & 36 & 28 & 18 \\
\hline & & & $\mathrm{a}$ & 117 & 207 & 121 & 88 & 533 \\
\hline & & & $\mathrm{b}$ & 291 & 406 & 269 & 138 & 798 \\
\hline 33 & 106 & Warszawa & $\mathrm{c}$ & 36 & 87 & 17 & 28 & 345 \\
\hline & & & $\mathrm{d}$ & 37 & 29 & 42 & 33 & 18 \\
\hline & & & $\mathrm{a}$ & 127 & 229 & 121 & 85 & 562 \\
\hline & & & $\mathrm{b}$ & 211 & 396 & 213 & 160 & 776 \\
\hline 36 & 120 & Wrocław & $\mathrm{c}$ & 66 & 119 & 37 & 38 & 323 \\
\hline & & & $\mathrm{d}$ & 27 & 30 & 33 & 32 & 18 \\
\hline
\end{tabular}


The values of summer precipitation provided by most of the stations range from 200 to $250 \mathrm{~mm}$, whereas the amount of winter precipitation ranges from 80 to $100 \mathrm{~mm}$. The values of spring and autumn precipitation generally fall within the same range - from 100 to $150 \mathrm{~mm}$. In spring and summer, the highest precipitation is recorded in the area of Tarnów and Jelenia Góra, and the lowest at the stations located in the northern regions of Poland - in Resko, Koszalin, and Ustka. In all seasons, the maximum seasonal precipitation sums were approximately two times higher than the mean sums. Greater differences, as compared to the means, were found for the minimum sums which were at least 2.5 times and in autumn even 4 times lower. For example, in Warsaw, Koło, and Kalisz, the minimum sums did not exceed $20 \mathrm{~mm}$ - Table 1. Generally, the extreme seasonal sums of precipitation were recorded at individual stations in different years - this is particularly evident as regards the maximum sums and the period of the calendar summer. In spring, by far the highest number of cases of maximum precipitation sums (11 stations) was recorded in 1970, in autumn 1974, and in winter - 1967. In turn, the minimum precipitation, which was recorded at more stations, occurred in the summer of 2015 and in the autumn of 1959.

The spectral analysis adopted in this study showed that in the period of 1951-2016, seasonal precipitation exhibited variation in numerous cycles of various length which, according to Kolmogorov-Smirnov d Bartlett and Fisher's Kappa, meet the criteria of statistical significance. The great majority of statistically verified cycles occurred in the winter season $(70 \%)$, less were recorded in summer $(57 \%)$. Spring showed higher occurrence of such cycles $(43 \%)$ than autumn $(38 \%)$. Out of the cycles determined for each of the stations, only those which were found to be predominant in a given season are presented in Fig. 4. Seven basic dominant cycles characterizing the multiannual variability of precipitation in the four seasons of a year were of the following length: 4.0, 4.6, 4.9, 5.3, 5.8, 6.4, and 7.1 years. Two of the aforementioned cycles, i.e., the 5.3 and 6.4-year-long ones were manifested in binary form in a few cases. 


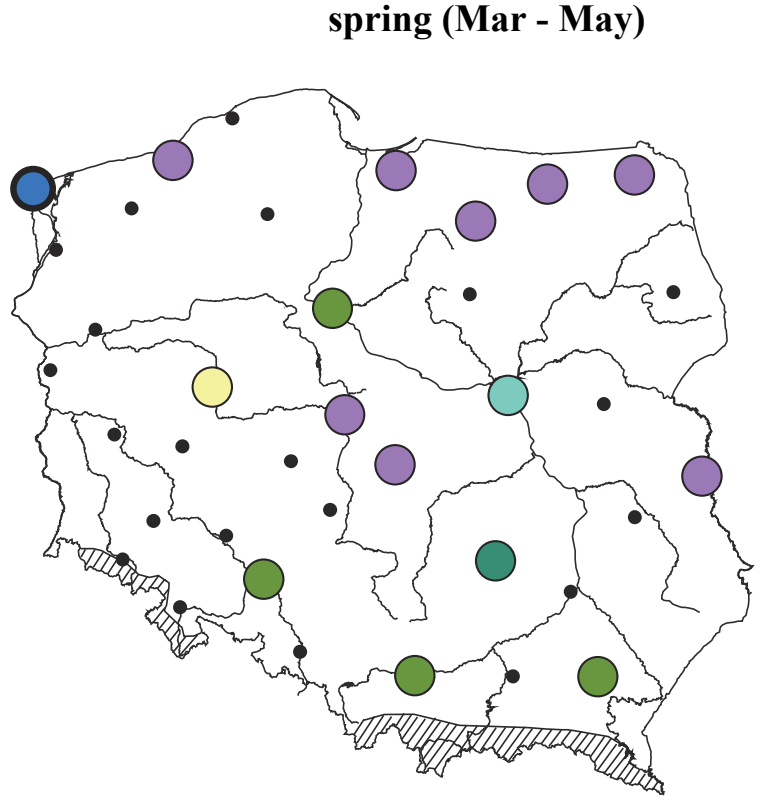

autumn (Sep - Nov)
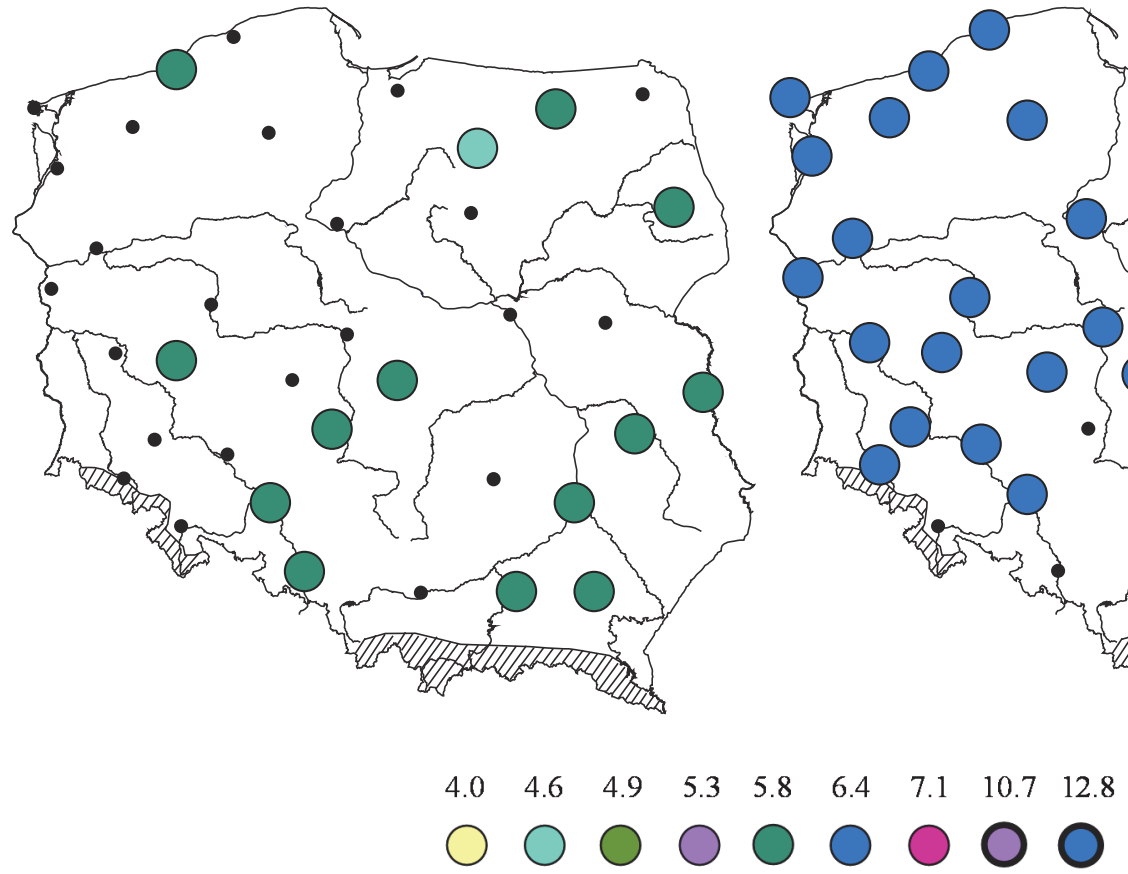

Fig. 4. Predominant cyclical elements in the distribution of seasonal precipitation in Poland, in the period 1951-2016.

Winter was the season in which the highest percentage of significant precipitation cycles was found. Moreover, in this season, the markedly dominant cycle, which occurred in most of the country, was 6.4-year-long. A relatively unified periodic variability of precipitation was determined in autumn, when the 
cycles were determined to last 5.8 years. Extremely scattered results, both in terms of the length of the cycles as well as spatial distribution, were found to occur in spring and summer. In summer, a relatively unified characteristics of variability of precipitation is particularly evident in the northern part of Poland. Seasonal precipitation in this region, but also at some stations in the south-east of Poland, exhibited variability in cycles of the same length as in winter, i.e., 6.4 years. Cycles of various length - from 4.9, 5.3, 7.1 to the doubled 5.3 cycle of 10.7, which were identified at stations located in close proximity, characterise variability of summer precipitation not only in Wielkopolska - the region with the minimum recorded precipitation (among others: Czarnecka and NidzgorskaLencewicz, 2012, Kędziora et al., 2014, Żarski et al., 2017), but also on the Silesian Lowlands. Individual temporal distribution of precipitation in the period 1951-2016 was identified for Poznan - not only in the summer season, but also in spring. Spring was characterized by the highest number and span of the identified cycles, including the isolated cycles. Apart from Poznań, the characteristic spring precipitation cycles were determined in the following regions: Warsaw (4.6 years), Kielce (5.8 years), and Świnoujście (12.8 years). At a few more stations, mainly in the north-east part of Poland, the dominant cycle in the temporal course of spring precipitation sums was 5.3-year-long.

The precipitation sums characterized above are not the only ones which were positively verified in terms of statistical significance. The analysis of periodograms and spectral density graphs for individual stations showed that in each season, apart from the dominant cycle, there were other equally marked cycles of various length. This is illustrated by the estimators given in Fig. 5, which were developed for the four seasons, however in the unified version for 37 stations which provide a good representation for the results obtained for most of the stations. In spring, apart from the dominant 5.3-year-long cycle, a slightly shorter cycle of 4.9 years was also pronounced. In the calendar summer, there was a cycle slightly weaker than 10.7 years (binary form of 5.3 cycle), i.e., it was 6.4-year-long, which was characteristic for the stations in the north of Poland. In autumn and winter, precipitation cycles considered significant are markedly weaker as compared with the dominant ones, that is: 5.8 and 6.4, respectively. In autumn, precipitation shows even shorter cycles - 3.6 year, while in winter the cycles were longer -9.1 years long. 

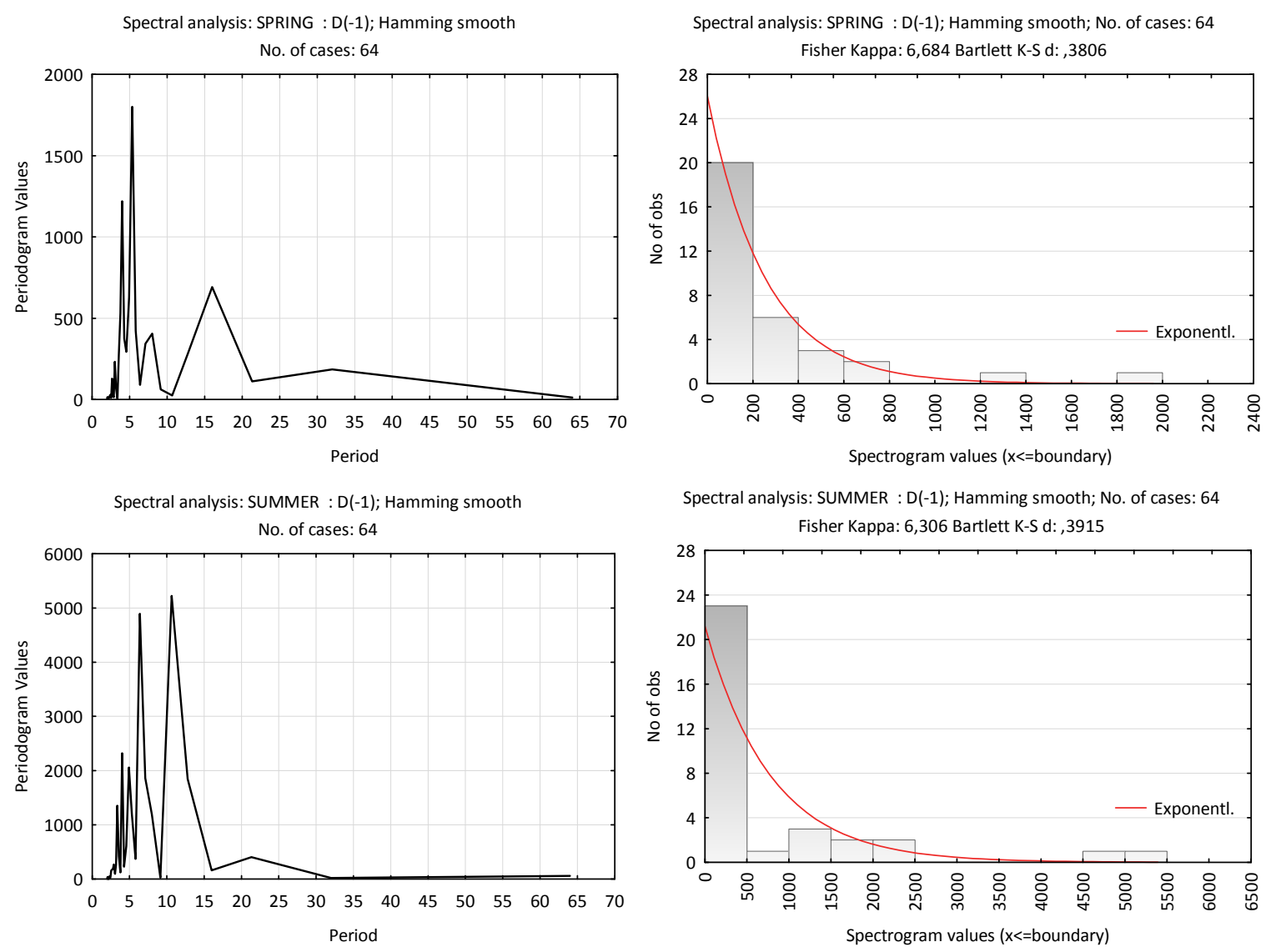

Spectral analysis: SUMMER : D(-1); Hamming smooth; No. of cases: 64

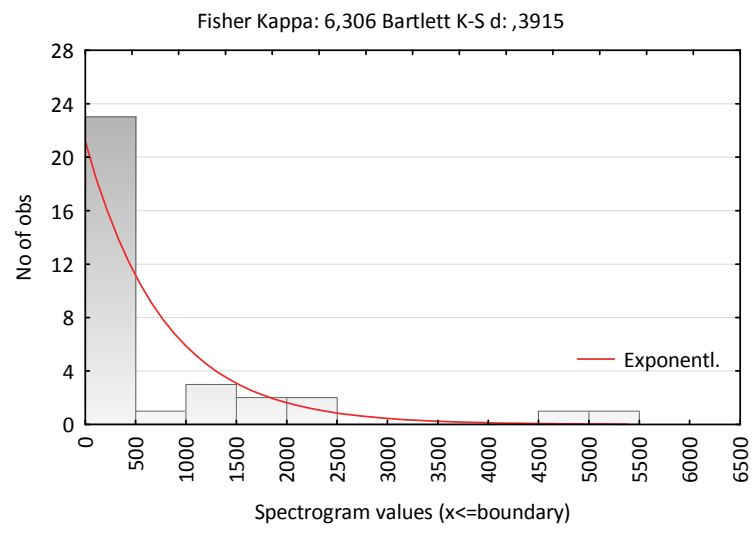

Spectral analysis: AUTUMN : D(-1); Hamming smooth

No. of cases: 64

Spectral analysis: AUTUMN : D(-1); Hamming smooth; No. of cases: 64
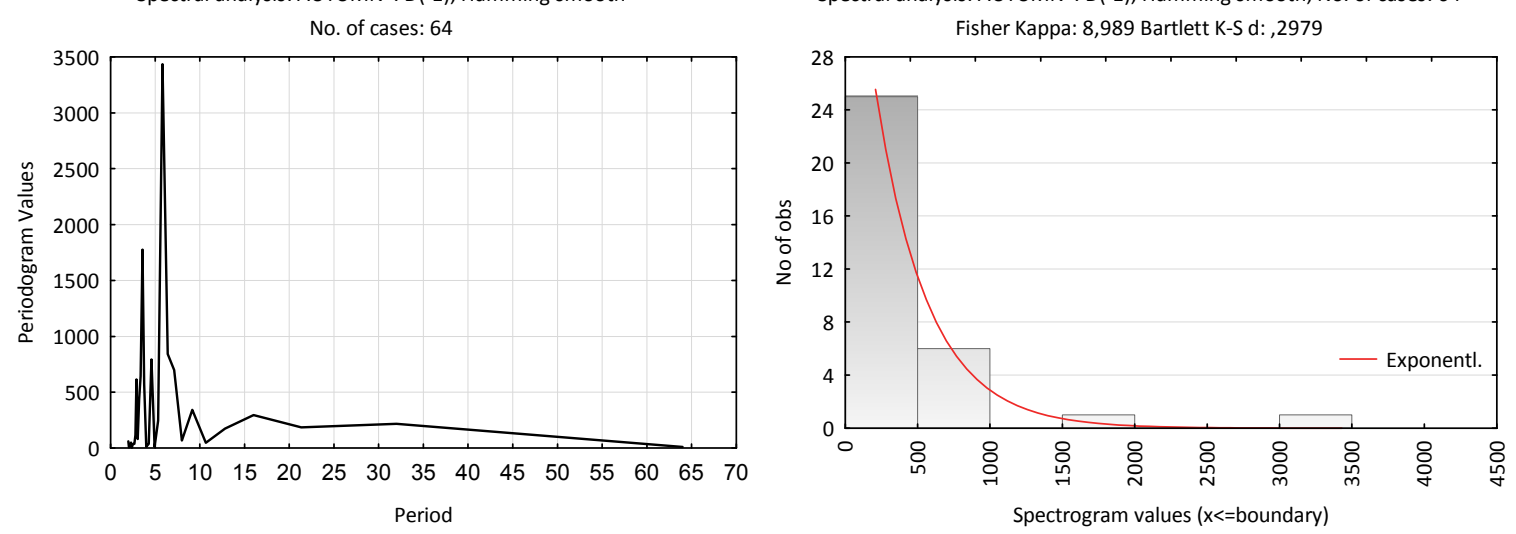

Spectral analysis: WINTER : D(-1); Hamming smooth

No. of cases: 64

Spectral analysis: WINTER : D(-1); Hamming smooth; No. of cases: 64

Fisher Kappa: 9,248 Bartlett K-S d: ,4353
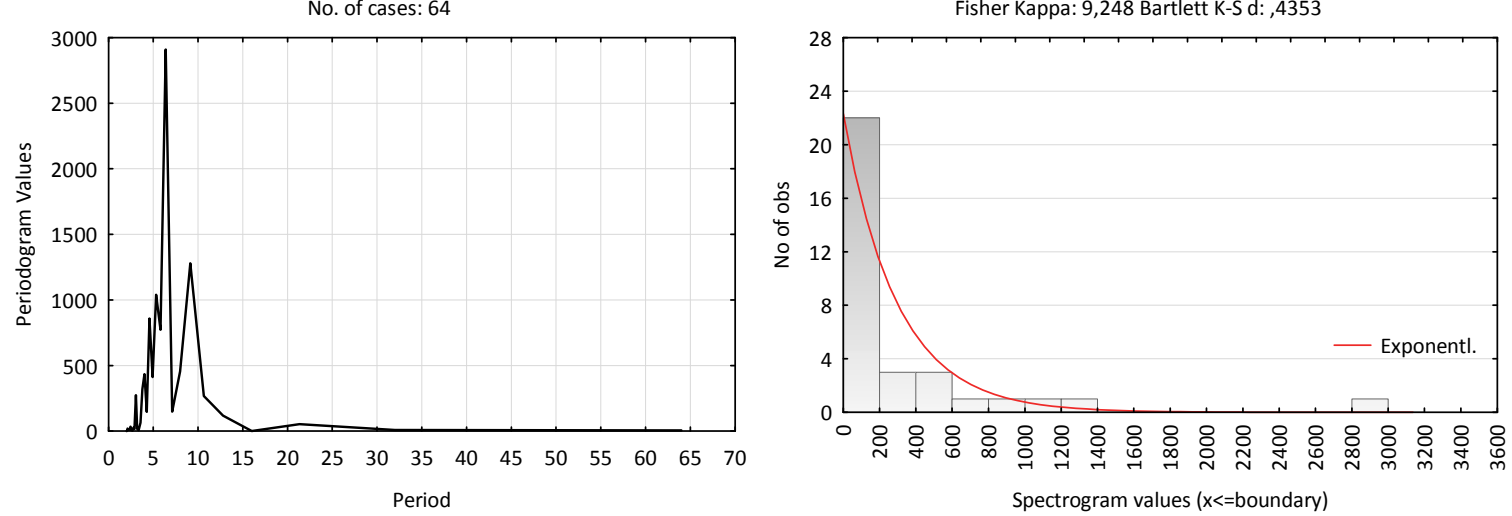

Fig. 5. Periodograms and histograms of periodogram values of seasonal total precipitation in Poland (values are averaged for 37 stations) in the period 1951-2016. 


\section{Conclusions}

The results of the spectral analysis showed that variability of seasonal precipitation in the period 1951-2016 occurred in numerous, statistically significant cycles. The dominant cycles were of the following length: 4.0, 4.6, $4.9,5.3,5.8,6.4$, and 7.1 years. The identified periodicity in the course of precipitation is markedly shorter as compared with the data on the changes in air temperature, which was also evaluated using spectral analysis (Gregorczyk and Michalska, 2011; Miętus, 1996). Numerous and relatively short cycles confirm both the very high inter-annual variability of this element, as well as spatial variability - as for 37 stations mainly regional variability is evident, however, local variability is also present. Undoubtedly, considering the results obtained from a greater number of stations would result in even higher variation as this element is marked by discontinuity and very high variability.

The most pronounced periodicity in the course of precipitation is characteristic for the winter season, whereas least regularity was identified for spring precipitation. In many regions in the north part of Poland, variability in winter and summer precipitation occurred in 6.4-year-long cycles.

It is difficult to compare the identified periodicity in the course of seasonal precipitation in the period 1951-2016 with the scarce results presented in the literature on the subject. The principal reasons of such lack of comparability, as was clearly emphasized by Miętus (1996), are notably the precipitation series of various length, as well as different methods of processing basic data when using spectral analysis.

\section{References}

Boryczka, J. and Stopa-Boryczka, M., 2000: Zmiany klimatu Polski w XVIII-XXI wieku. Acta UNC Toruń, Nauki Mat. Przyrod., 106, Geografia 31, 65-89. (in Polish)

Boryczka, J. and Stopa-Boryczka, M., 2004: Cykliczne wahania temperatury powietrza i opadów w Polsce w XIX I XXI wieku. Acta Agrophysica 3, 21-33. (in Polish)

Czarnecka, M. and Nidzgorska-Lencewicz, J., 2012: Wieloletnia zmienność sezonowych opadów w Polsce. Woda-Środowisko-Obszary Wiejskie 12, 2(38), 45-60. (in Polish)

Czarnecka, M. and Nidzgorska-Lencewicz, J., 2016: The cyclical nature of seasonal precipitation in Pomerania in the period 1951-2010. Russian Meteorol. Hydrol. 4, 27-36. https://doi.org/10.3103/S1068373916040038

Degirmendžić, J., Kożuchowski, K., and Żmudzka E., 2004: Changes of air temperature and precipitation in Poland in the period 1951-2000 and their relationship to atmospheric circulation. Int. J. Climatol. 24, 291-310. https://doi.org/10.1002/joc.1010

Doroszewski, A., Jóźwicki, T., Wróblewska, E., and Kozyra, J., 2014: Susza rolnicza w Polsce w latach 1961-2010. Instytut Uprawy Nawożenia i Gleboznawstwa Państwowy Instytut Badawczy, Puławy. (in Polish)

Fortuniak K., 2004: Wybrane metody poszukiwania okresowej zmienności w szeregach klimatycznych. In (Eds. A. Bokwa , Z. Ustrnul) Zastosowanie wybranych metod statystycznych w klimatologii, Wydawnictwo Instytutu Geografii i Gospodarki Przestrzennej, U.J., Kraków, 31-52. (in Polish) 
Gregorczyk, A. and Michalska, B., 2011: Zmienność temperatury powietrza w Szczecinie. Acta Agrophysica 17, 301-309. (in Polish)

Kaszewski, B., 2015: Zmiany klimatu Polski w pracach polskich klimatologów. Przeglad Geofizyczny 3-4, 217-235. (in Polish)

Kędziora, A., Kępińska-Kasprzak, M., Kowalczak, P., Kundzewicz, S.W., Miler, A.T., Pierzgalski, E., and Tokarczyk T., 2014: Zagrożenia związane z niedoborem wody. Nauka 1, 149-172. (in Polish)

Kirschenstein, M. and Baranowski, D., 2005: Sumy opadów atmosferycznych w Polsce w latach 19511995. Badania Fizjograficzne nad Polską Zachodnią, Seria A, Geografia Fizyczna, 56, 55-72. (in Polish)

Kożuchowski, K., 1996: Współczesne zmiany klimatyczne w Polsce na tle zmian globalnych. Przegląd Geograficzny 68), 79-98. (in Polish)

Kożuchowski, K., 2004: Zmienność opadów atmosferycznych w Polsce w XX i XXI wieku. In (Ed.: K. Kożuchowski) Skala, uwarunkowania i perspektywy współczesnych zmian klimatycznych w Polsce. Wydawnictwo Biblioteka, Łódź, 47-58. (in Polish)

Eupikasza, E., 2010: Spatial and temporal variability of extreme precipitation in Poland in the period 1951-2006. Int. J. Climatol. 30, 991-1007. https://doi.org/10.1002/joc.1950

Mager, P., Kasprowicz, T., and Farat, R., 2009: Change o air temperature and precipitation in Poland in 1966-2006. [In: Climate change and agriculture in Poland - impacts, mitigation and adaptation measures. Acta Agrophysica, Rozprawy i Monografie 169, 19-38.

Marosz, M., Wójcik, R., Biernacik, D., Jakusik, E., Pilarski, M., Owczarek, M., and Miętus, M., 2011: Zmienność klimatu Polski od połowy XX wieku. Rezultaty projektu klimat. Prace $i$ Studia Geograficzne 47, 51-66. (in Polish)

Miętus M., 1996: Zmienność temperatury i opadów w rejonie polskiego wybrzeża Morza Bałtyckiego i jej spodziewany przebieg do roku 2030. Materiaty Badawcze IMiGW, Seria Meteorologia, 26, (in Polish).

Miler, A.T. and Miler, M., 2005: Trendy i okresowości zmian temperatury oraz opadów dla Poznania w latach 1848-2000. Zeszyty Naukowe Wydziału Budownictwa i Inżynierii Środowiska Politechniki Koszalińskiej, Inżynieria Środowiska 22, 945-956. (in Polish)

Miler, A.T. and Okoński, B., 2011: Zmiany klimatyczne w Puszczy Zielonka od 1848 roku. Infrastruktura i Ekologia Terenów Wiejskich 2, 193-203. (in Polish)

Skowera, B., Kopcinska, J., and Kopeć, B., 2014: Changes in thermal and precipitation conditions in Poland in 1971-2010. Ann. Warsaw Univ. of Life Sci. - SGGW, Land Reclamation 46, 153-162. https://doi.org/10.2478/sggw-2014-0013

Skowera, B., Kopcińska, J., and Bokwa, A., 2016: Changes in the structure of days with precipitation in Southern Poland in 1971-2010. Idöjárás 120, 365-381.

Szwed, M., 2018: Variability of precipitation on Poland under climate change. Theor. Appl. Climatol.135, 1003-1015. https://doi.org/10.1007/s00704-018-2408-6

Twardosz, R. and Cebulska, M., 2005: Periodical changes of precipitation and the number of precipitation days in Cracow. Prace Geograficzne 115, 49-56.

Ziernicka-Wojtaszek, A., 2006: Zmienność opadów atmosferycznych na obszarze Polski w latach 19712000. In (Eds.: J. Trepińska, Z. Olecki]) Klimatyczne aspekty środowiska geograficznego. Instytut Geografii i Gospodarki Przestrzennej Uniwersytetu Jagiellońskiego, Kraków, 139-148. (in Polish)

Żarski, J., Dudek S., Kuśmierek-Tomaszewska, R., Bojar, W., Knopik, L., and Żarski, W., 2014: Agroklimatyczna ocena opadów atmosferycznych okresu wegetacyjnego w rejonie Bydgoszczy. Infrastruktura i Ekologia Terenów Wiejskich, II/3, 643-656 (in Polish). http://dx.medra.org/10.14597/infraeco.2014.2.2.047

Żarski, J., Dudek, S., Kuśmierek-Tomaszewska, R., and Żarski, W., 2017: Effects of agricultural droughts in the province of kujawsko-pomorskie and possibilities of minimizing their impact. Infrastruktura i Ekologia Terenów Wiejskich, II/2, 813-824. http://dx.medra.org/10.14597/infraeco.2017.2.2.063

Żmudzka E., 2002.: O zmienności opadów atmosferycznych na obszarze Polski nizinnej w drugiej połowie XX wieku. Wiadomości IMGW 25(46), 4, 23-38 (in Polish).

Żmudzka E., 2009: Współczesne zmiany klimatu Polski. Acta Agrophysica 13, 555-568. (in Polish) 